"نشريه علوم زراعى ايران"

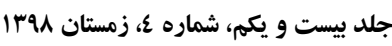

مقاله يثوهشى

اثر زمان كاشت و ميزان كود نيتروزن بر رشد، عملكرد دانه و كارايى مصرف نيتروزن كينوا در شرايط اقليمى اهواز (Chenopodium quinoa Willd)

Effect of sowing time and nitrogen fertilizer rates on growth, seed yield and nitrogen use efficiency of quinoa (Chenopodium quinoa Willd) in Ahvaz, Iran

$$
\begin{aligned}
& \text { سرور الملو كك سعيدى'، سيد عطاءاله سيادت r'، على مشتطى '، محمدرضا مر ادى تلاوت } \\
& \text { نيازعلى سيهونده } \\
& \text { جكيده }
\end{aligned}
$$

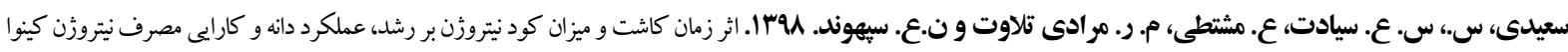
(Chenopodium quinoa Willd)

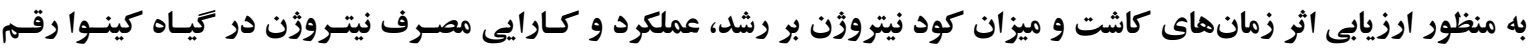

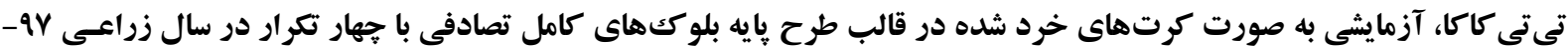

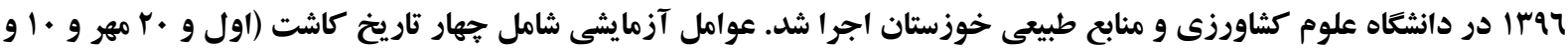

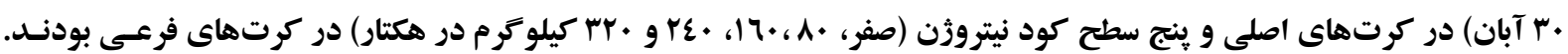

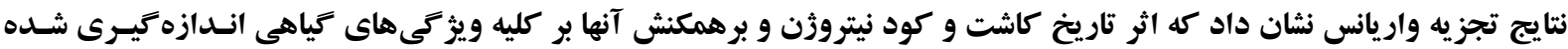
معنى دار بودند. نتايج مقايسه ميانكينها نشان داد كه بيشترين تعداد دان دانه در بوته

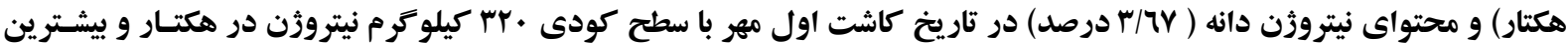

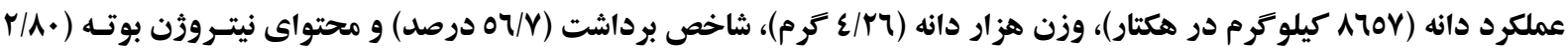

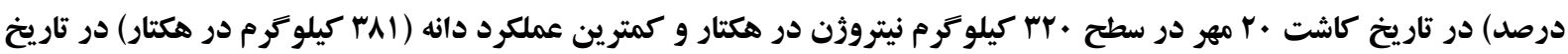

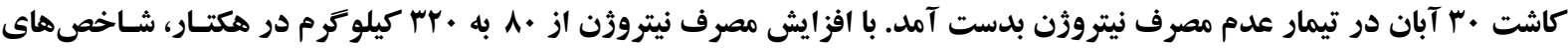

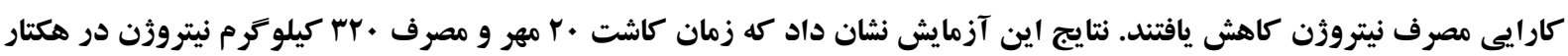

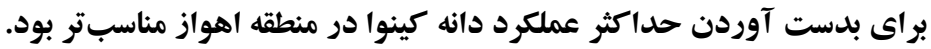
وازههاى كليدى: خوزستان، شاخص برداشت، كود اوره، كينوا و وزن هزار دانه.

\footnotetext{
اين مقاله مستخرج بايان نامه كارشناسى ارشد نغارنده اول مى باشد.

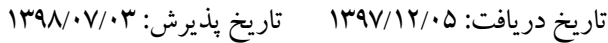
1- دانشجوى سابق كارشناسى ارشد دانشكده كشاورزى دانشكاه علوم كشاورزى و منابع طبيعى خوزستان

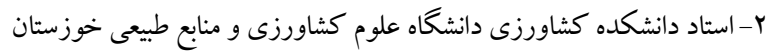

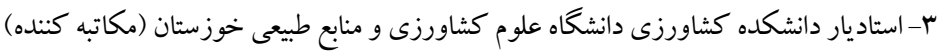

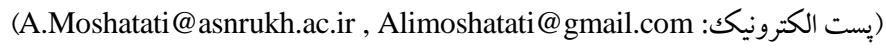
ץ- دانشيار دانشكده كشاورزى دانشگاه علوم كشاورزى و منابع طبيعى خوزستان ه- استاديار موسسه تحقيقات اصلاح و تهيه نهال و بذر دمر درد
} 


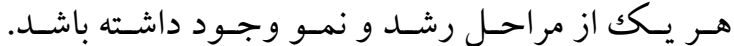

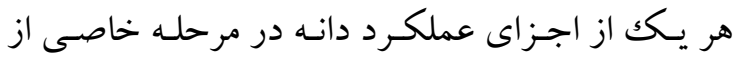

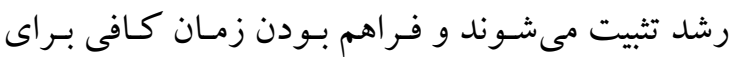

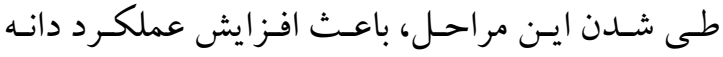

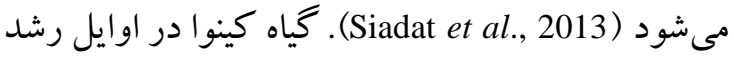

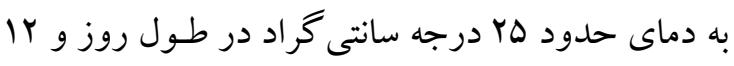

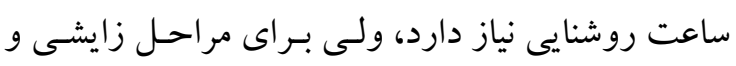

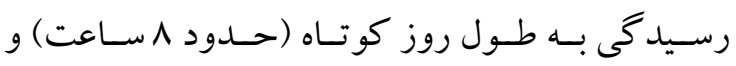

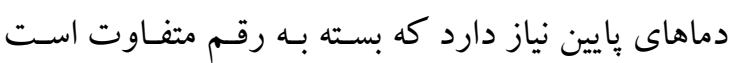
(Sepahvand and Sheikh, 2011) بهتـرين تـاريخ كاشـت كينـوا در شـرايط آب و هـوايى

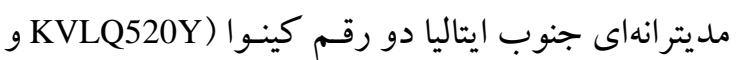

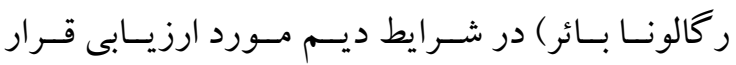

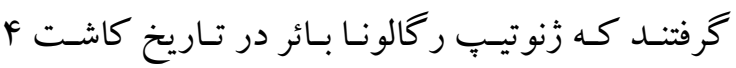

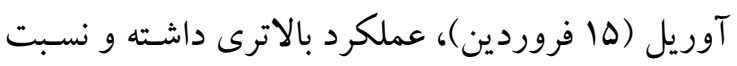

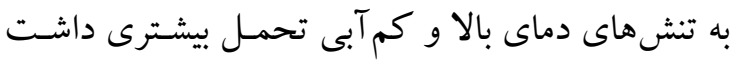

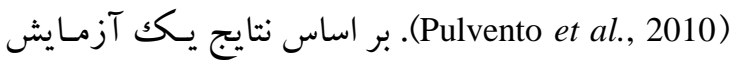

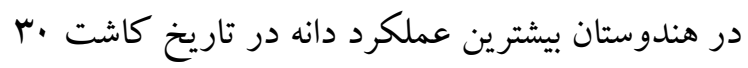
نوامبر ( •ا آذر) به دست آمد (Bhargava et al., 2006). در يـكك آزمـايش در ايـران دو رقـم كينـوا (سـاجاما و

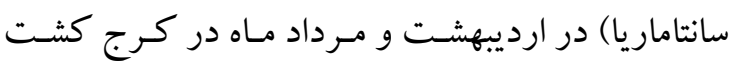

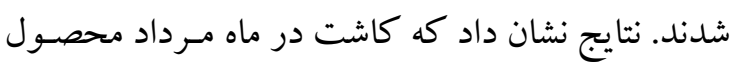
مناسب ترى توليد كرد، ولى كاشت در ماه ارديبهشت، بال

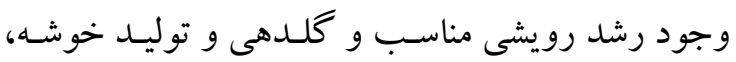

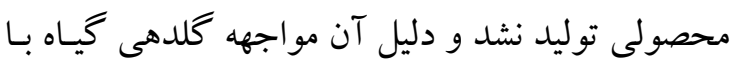

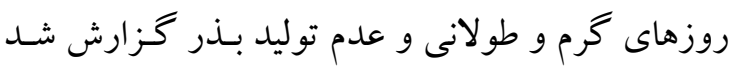
(Sepahvand et al., 2010)

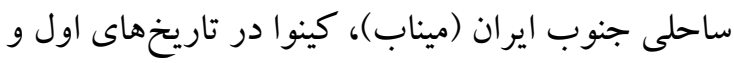

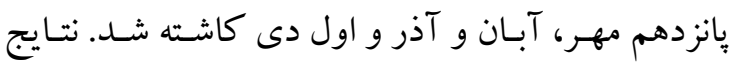

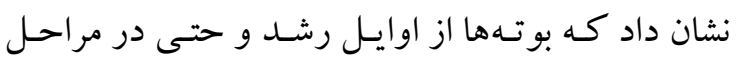

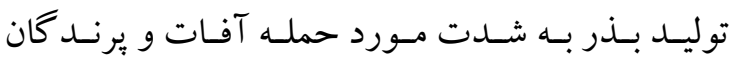

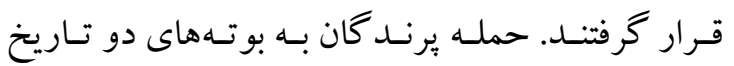

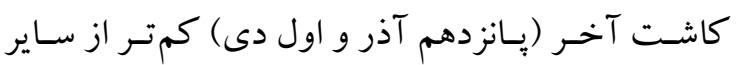

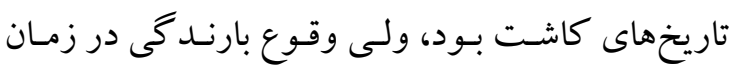

\section{مقدمه}

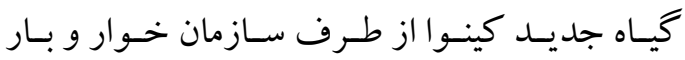

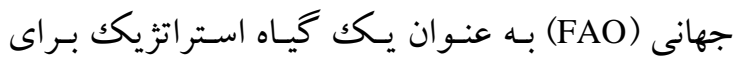

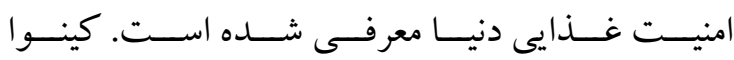
كياهى دو لِّه با حسدود (Chenopodium quinoa Willd)

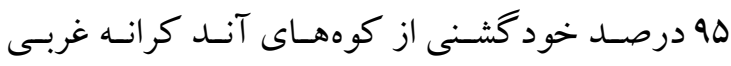
آمريكاى جنوبى منشـأ گرفتـه اسـت (Jacobsen, 1998). كينوا گياهى يكساله، بيهنبر گك با ارتفاع يكك تـا دو متر

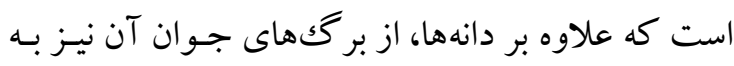
عنوان سبزى تازه و يا به صورت بخته استفاده مى شـود.

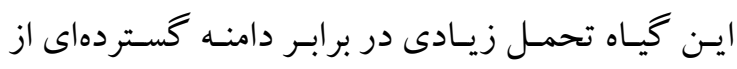

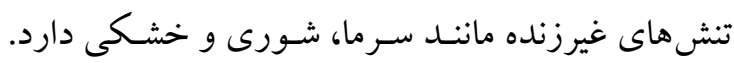
كينوا به دليل كيفيت بالاى دانه و تحمل زياد بـه شـرايط

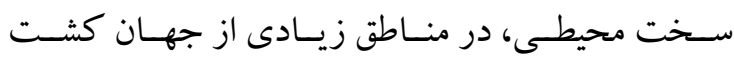

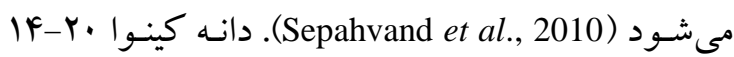
درصسـد يــروتئين دارد و سرشــار از اسـيدهاى آمينــه

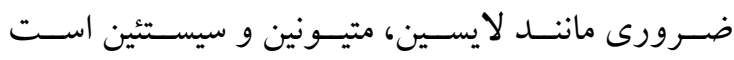
كه در بيشتر غلات به ميزان خيلى كـم وجسود دارد

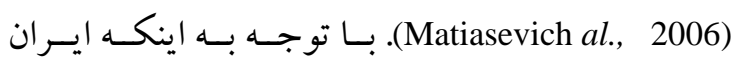
كشورى با تنسوع آب و هـواى فراوان و جمعيتى رو بـــ

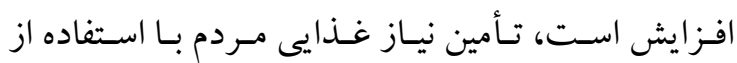
يتانسـيل توليــات كشـاورزى از ضــروريات و الزامـات كشورى اسـت (Sepahvand et al., 2010). كشـت كيـاه

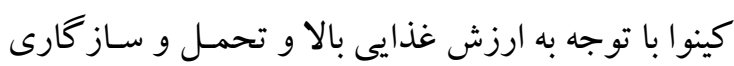

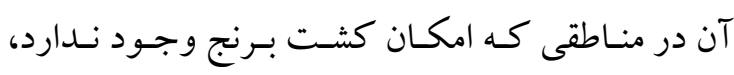

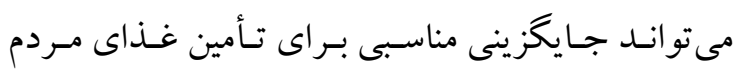

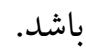
زمان كاشت گ گيـاه در هـر منطقـهـ بـهـ شـر ايط اقليمسى

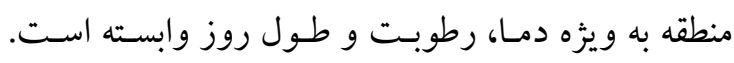

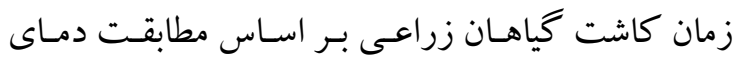

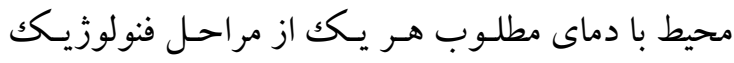
رشد و همجنين عدم مصادف شدن مراحل حساس رشد

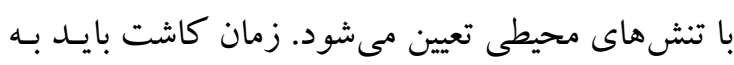

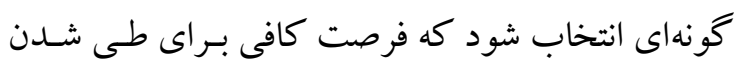


عملكرد دانه كينوا در شـرايط آب و هـوايى مديترانسهاى نشان داد كه بهترين ميزان نيتروزن بـراى توليـد بيشـترين عملكرد دانه، شاخص برداشـت و وزن هـزار دانـه، • 10

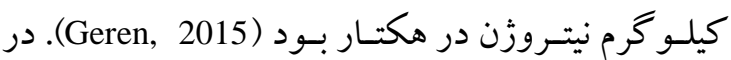

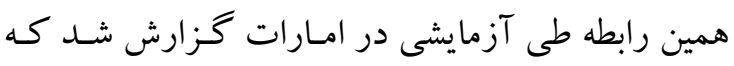

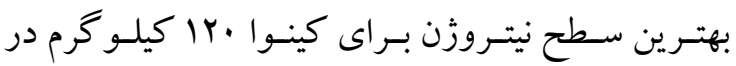
هكتـار اسـت (Mosseddaq et al., 2016). بـر اسـاس نتايج آزمايشى كه در ملاثانى اهواز انجام شـد، افـزايش

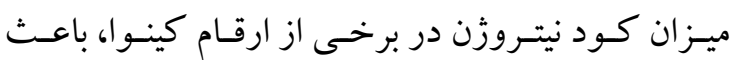

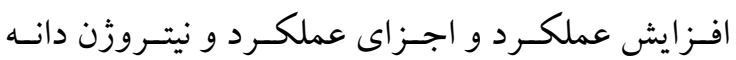
و بوتسه كرديسـ. بـين سـطوح كـود نيتـروزن و ارقـام از لحاظ تعداد شاخه هاى فرعى، ارتفــاع بوتـه، قطر سـاقه، تعداد و وزن گل آذين در بوته، تعداد دانه در گَل آذين، وزن هزاردانه و عملكرد دانسه، عملكـرد مـاده خشكك و وله شـاخص برداشـت تفــاوت معنـى دارى وجــود داشـت

.(Shahmansouri, 2015)

با توجه به اينكه تعيين تاريخ كاشت مناسب و ميـزان مصرف بهينه كود نيتروزن بر رشد و عملكـرد كيـاه اثر دارد، اين يزوهش با هدف ارزيابى اثر تـاريخ كاشـت و مقدار كود نيتروزن بر صـفات رشـدى، عملكـرد دانـه و كارايى مصرف كود نيتروزن در كينوا در شـرايط آب و هوايى اهواز انجام شد.

\section{مواد و روشها}

اين آزمـايش در سـال زراعى 9V-9ها در مزرعـه

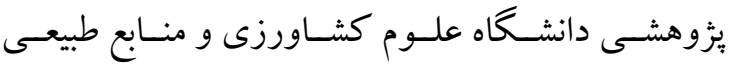
خوزستان در وس كيلومترى شمال شرقى اهـواز و حاشسيه شرقى رودخانه كارون باعرض جغرافيـايى اس درجـه و هr دقيقه شمالى و طول جغرافيايى FA درجه و rه دقيقـه شرقى و ارتفاع F متر از سطح دريا اجرا شد. بـر اسـاس آمار هواشناسى، منطقـه ملاثـانى جـزء منـاطق خشـك و و نيمه خشك محسوب مى شـود (جـدول ()). آزمـايش بـه

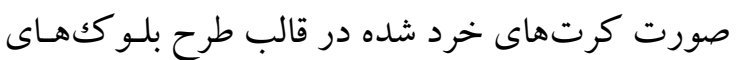

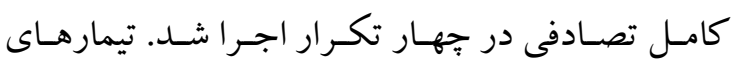

ظهور گياهجه باعث از بين رفتن بوتهها بـه دليـل مـرك

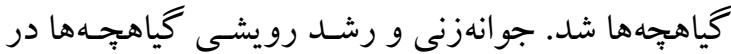
كشت هاى اول مهر تا يانزدهم آبان مناسب بود، ولى بـا سرد شـدن هـوا، سـرعت رشـد رويشى كـاهش يافته و كياهان در ارتفاع كوتاهترى وارد مرحله زايشسى شـدند (Hasanzadeh et al., 2014). در يكك آزمايش اثر جهـار تاريخ كاشت ( •ا و هr مهر و · او هY آبان) بر سه رقم ساجاما، ساجاما ايرانشهر و سانتاماريا كينوا در خوزستان بررسى شد. نتايج نشان داد كه تـأخير در كاشـت باعـث تأخير در مراحل فنولوزيك هميجون جوانهزنى، كلـدهى لتهى

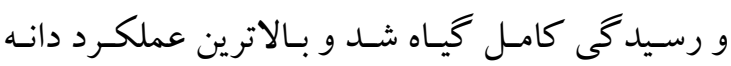
مربوط به تاريخ كاشت · ا مهر و رقم سـاجاما ايرانشهر بود (Tavoosi and Sepahvand, 2014).

نيتـروزن در تشـكيل اسـيدهاى آمينـه، ويتـامينهـا و كلروفيـل شــركت دارد. اخـــر نيتــروزن بــه مقــدار كـافى در دسـترس كيــاه قــرار كيــرد، باعــث افـزايش

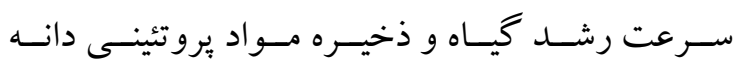
مى شــود (Siadat et al., 2013). ارلـى و همككـاران كزارش كردند كه كينوا به شــدت (Erley et al., 2005) به مصرف كود نيتروزن واكنش نشـان مىدهـد. برتى و

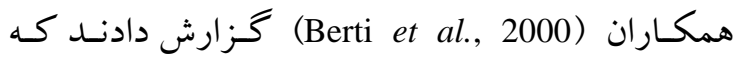
بيشترين عملكرد دانه كينـوا بـا بـالاترين ميـزان مصـرف نيتروزن (هY (ه كيلو گرم در هكتار) به دست آمد. وجسود مقادير زياد نيتروزن باعث كاهش عملكرد دانه مىشود،

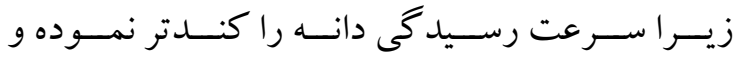
باعث افزايش رشد رويشى كياه مىشـود. مصـرف كود نيتــروزن باعـث افـزايش عملكــــد دانـه و نيـز افـزايش برو تئين دانسه مى شود (Williams and Brenner, 1995). كومـا (Goma, 2013) گَزارش كرد كـه كـود نيتـروزن باعث افزايش رشد رويشسى و رونـــ سـوخت و سـاز در كينـوا و همجنــين افـزايش تجمـع مـاده خشـك كيــاه مىشـود. نتـايج يـك آزمـايش انجـام شـده در دانشـكاه ازمير تركيه در خصوص اثر سطوح كود نيتروزن (صفر،

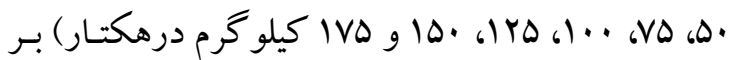


شد و بِ از استقرار كامل بوتههـا، فاصـله بوتهها روى

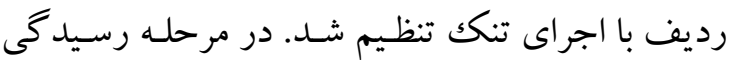

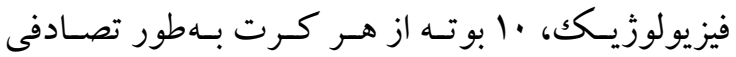
انتخــاب و بــراى انـدازه گيرى وزن هز اردانسه، دو تكـرار

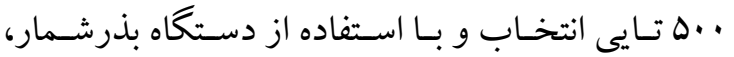
شمارش و توزين شدند. براى اندازه گيرى عملكرد دانسه

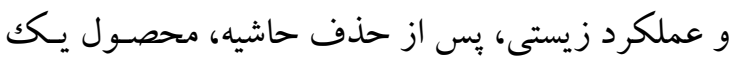
مترمربع از هر كرت به صورت دستى كفتبر و برداشـت

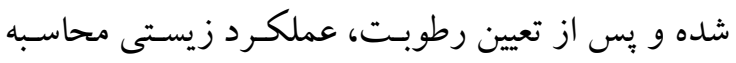

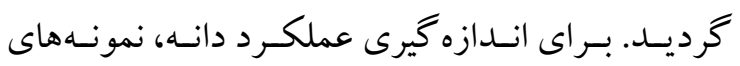
مربوط به هر كرت آزمايشى به صورت جداكانه تـوزين

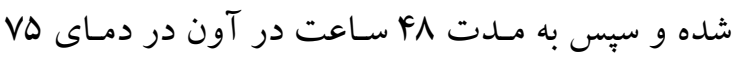
درجه سانتى گر اد خشكانده شده و مجدداً تـوزين شـدند

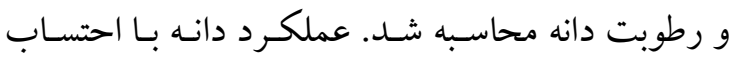
رطوبـت Y I درصـد محاسـبه شـد. شـاخص برداشـت از

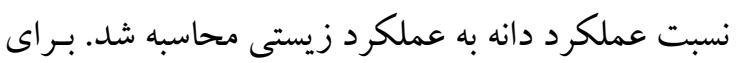

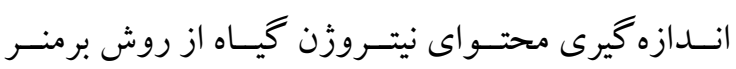
و براى محاسبه شاخص هـاى كـارايى (Bremner, 1996) زراعى نيتروزن، كارايى فيزيولوزيك نيتروزن و كـارايى بازيافت ظاهرى نيتروزن از رابطههاى ا تا ب استفاده شـد

(Fageria, 2009)
آزمايشى شامل جهار تاريخ كاشت (اول و ·r مهر و . 1. و ·r آبان، در كرتهاى اصـلى) و يـنج سـطح نيتـروزن

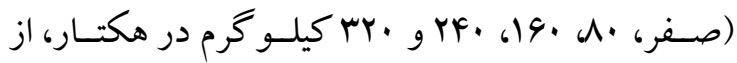
منبع اوره، در كرتهاى فرعى) بودند. هر كرت فرعى شامل شش خط كاشت به طول سه متر و فاصله خطوط •4 سانتى متر بود. رقـم كينـوا مـورد كشـت، تىتى كاكـا. بومى كشور بوليوى و برو، با طـول دوره رشـد ، . 1-

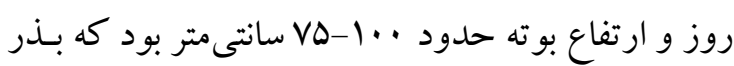
آن از مركز تحقيقات كشاورزى ايرانشهر تهيـه شـد. بـر اساس نتايج آزمون خاكك، مقدار •ه كيلو كرم در هكتار

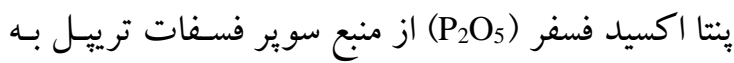
صورت بايه قبل از كاشت بـه خـاكك داده شـد (جـدول

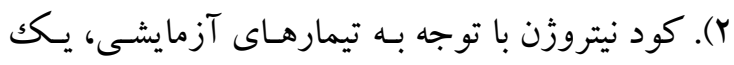

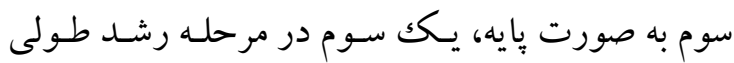

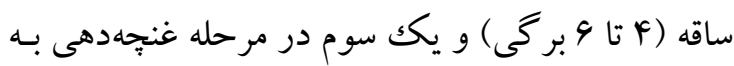
خاكك داده شد. روش كاشت به صـورت جـوى و يشـته بود و بــرها در عمـق ه/ ا تـا دو سـانتى مترى خـاكك بـا تراكم 19 بوته در مترمربع كاشـته شـدند. كليـه عمليـات زراعى براى همه كرت ها به طور يكنو اخت انجام شد. با

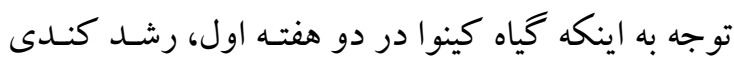
دارد، براى مبارزه با علف هاى هرز وجـين دسـى انجـام

عملكرد دانه بدون مصرف كود نيتروزن- عملكرد دانه با مصرف كودنيتروزن

(رابطه ()

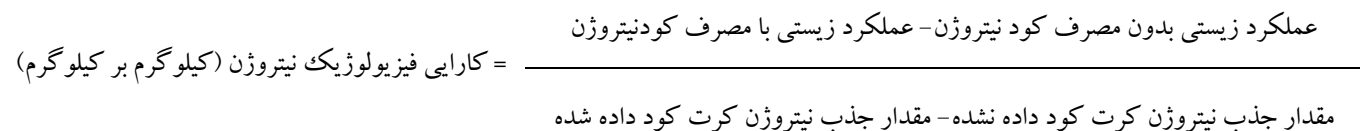


" اثر زمان كاشت و ميزان كود نيتروزن....، سعيدى و همكاران، 1HAF-rGV

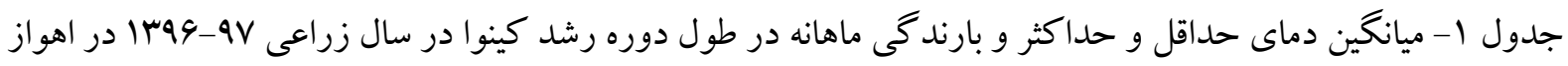

Table 1. Mean of monthly minimum and maximum temperatures and precipitation during quinoa growth

\begin{tabular}{|c|c|c|c|c|}
\hline Month & ماه & $\begin{array}{c}\text { ميانگين دماى حداقل } \\
\text { Mean of Min. temperature }\left({ }^{\circ} \mathrm{C}\right)\end{array}$ & $\begin{array}{c}\text { ميانگين دماى حداكثر } \\
\text { Mean of Max. temperature }\left({ }^{\circ} \mathrm{C}\right)\end{array}$ & $\begin{array}{c}\text { بارندگى } \\
\text { Precipitation (mm) } \\
\end{array}$ \\
\hline Oct. & مهر & 19.4 & 38.1 & 0 \\
\hline Nov. & آبان & 14.5 & 31.7 & 0 \\
\hline Dec. & آذر & 7.3 & 22.1 & 18.9 \\
\hline Jan. & دى & 8.2 & 22.9 & 2.7 \\
\hline Feb. & بهمن & 8.1 & 22.7 & 7.2 \\
\hline Mar. & اسفند & 12.8 & 27.1 & 27.9 \\
\hline
\end{tabular}

جدول r- مشخصات فيزيكى و شيميايى خاكك محل اجراى آزمايش (عمق صفر تا ·r سانتىمتر)

Table 2. Physical and chemical properties of soil in the experiment site $(0-30 \mathrm{~cm}$ soil depth)

\begin{tabular}{|c|c|c|}
\hline $\mathrm{EC}\left(\mathrm{dS} . \mathrm{m}^{-1}\right)$ & هدايت الكتريكى & 4.1 \\
\hline \multicolumn{2}{|l|}{$\mathrm{pH}$} & 7.6 \\
\hline Organic matter $(\%)$ & 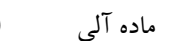 & 0.50 \\
\hline $\mathrm{N}(\%)$ & نيتروزن & 0.06 \\
\hline $\mathrm{P}\left(\mathrm{mg} \cdot \mathrm{kg}^{-1}\right)$ & فسفر & 8.2 \\
\hline $\mathrm{K}\left(\mathrm{mg} \cdot \mathrm{kg}^{-1}\right)$ & يتاسيم & 135 \\
\hline Soil texture & بافت خاكك & Silty clay \\
\hline
\end{tabular}

محيطى موثر بـر تعـداد دانـهــا، دمـا اسـت. طاووسىى و

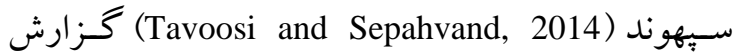
كردند كه با تـاخير در كاشـت كينـوا، بـه دليـل افزايش

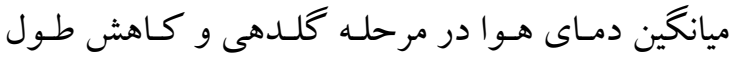
دوره تشـكيل دانسهها، تعـداد دانـه در بوتـه ارقـام كينـوا

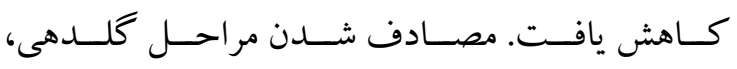

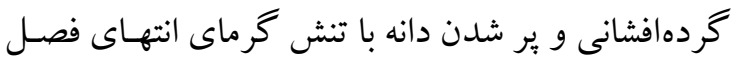
باعث كاهش عملكرد دانه در اثر كـاهش تعـداد دانسه و وزن هزاردانه مىشود. نتايج حاصل نشان داد كه افزايش

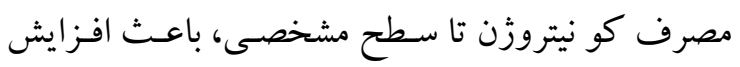

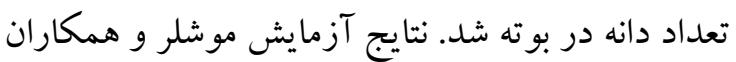

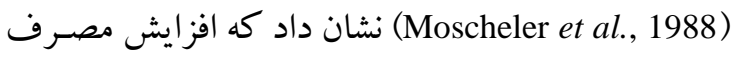
نيتروزن در ذرت باعـث افزايش تعـداد دانه در رديـف

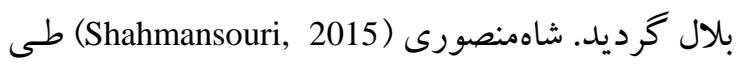

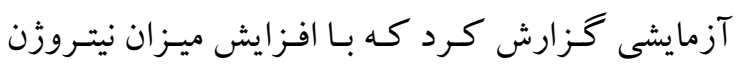
مصرفى، به دليل افزايش رشـد رويشى و فراهمى مـواد فتوسنتزى، تعداد دانه در بوته كينوا افزايش يافت.

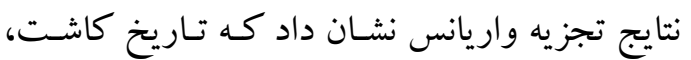

تجزيسه دادههــا بــا اسـتفاده از نرمافـزار SAS و مقايسـه ميانكين ها با استفاده از آزمـون LSD در سـطح ادهـ احتمـال

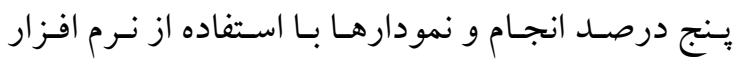

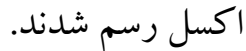

\section{نتايج و بحث}

نتايج تجزيه واريانس نشان داد كه اثر تاريخ كاشت،

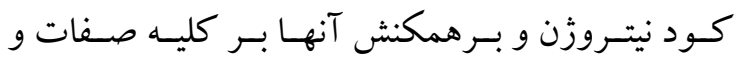

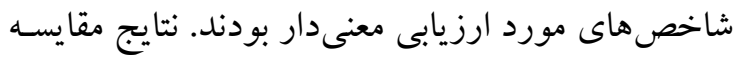

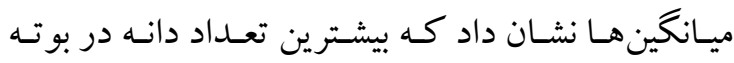

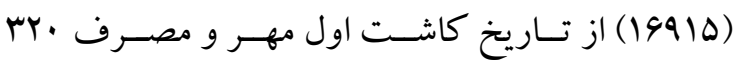

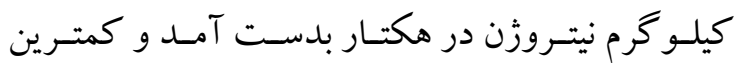

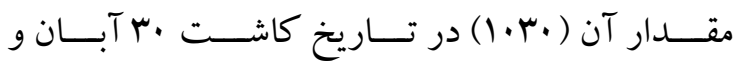
عدم مصرف كود نيتروزن مشاهده شد (جدول r). نتايج

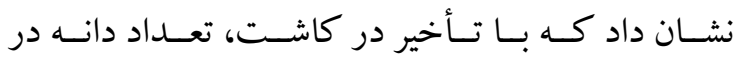
بوته كاهش يافت كه علت ايـن كـاهش را مىتـوان بـه

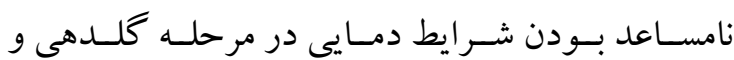

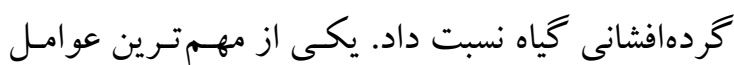


كشت اول مهر و تيمار •.ب كيلو گرم نيتروزن در هكتار تفاوت معنىدارى نداشت (جدول ץ). كمترين عملكرد

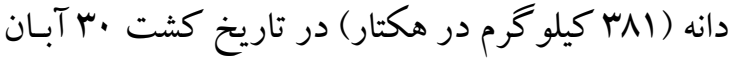

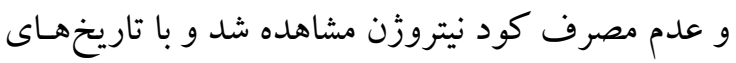
كشت ديخر در همين سطح تفاوت معنسى دارى نداشـت.

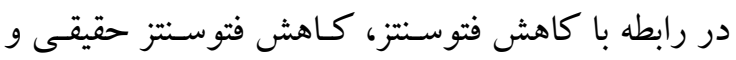

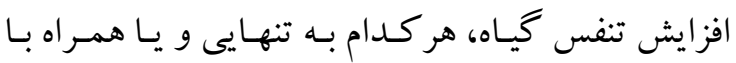

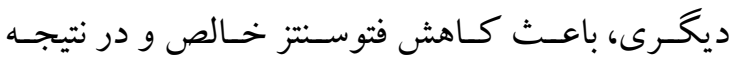

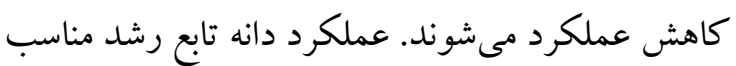

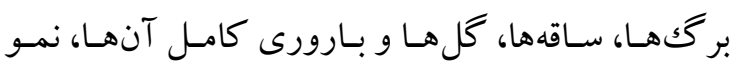
جنين، تجمع نشاسته و بروتئين در دانهه و عرضسه مستمر

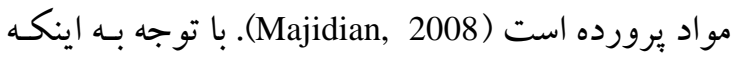
تاريخ كاشت در مناطق و شرايط آب و هوايى مختلف، بروده

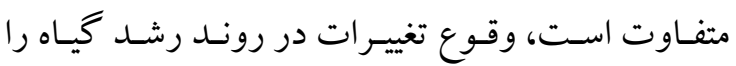

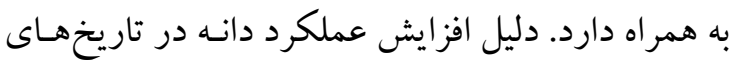

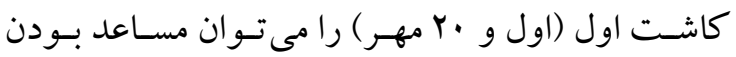

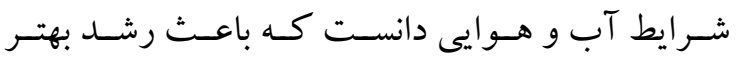

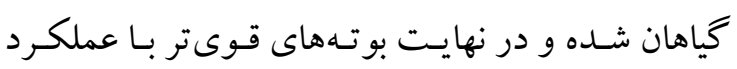
بيشتر توليد نمايند. در تاريخ كاشت اول و دوم بـه دليـل

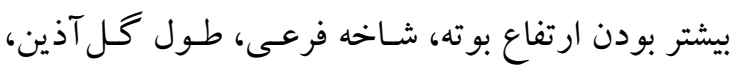

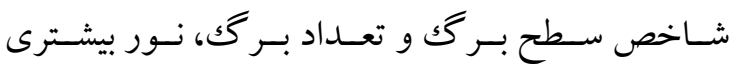

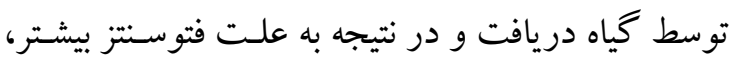
سرعت رشد گياه و تجمع ماده خشك نيز افزايش يافتـه

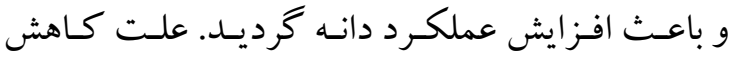

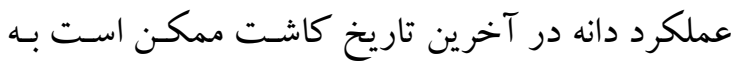

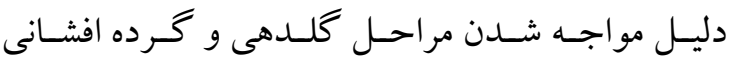

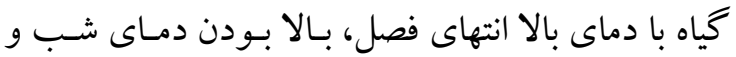

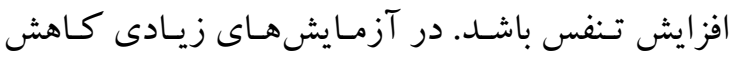

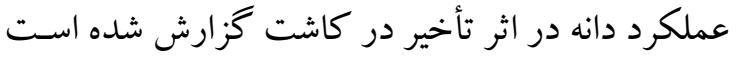
(Tavoosi and Sepahvand, 2014; Fathi et al., 2001 در.Bakhshandeh et al., 2016; Abodeh, 2017;) آزمايش حاضر با افزايش ميزان نيتروزن، عملكـرد دانـه

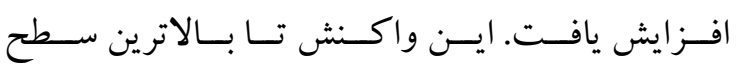

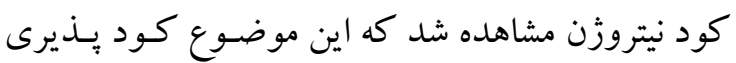

كـود نيتـروزن و بـرهمكنش آنهـا بـر وزن هزاردانـه در سطح احتمال يكك درصد معنىدار بود. بيشترين ميانگين

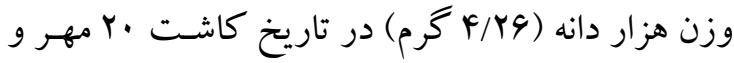

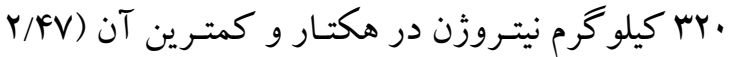

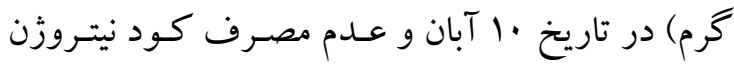
بدست آمد و با تاريخ كشـت · ب آبـان در همـين تيمـار كودى تفاوت معنىدارى نداشت (جدول ب). وزن هـزار

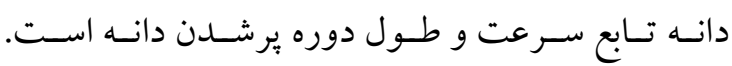

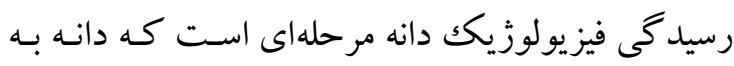

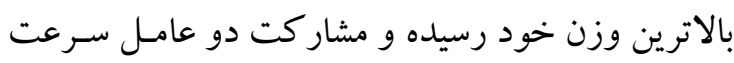

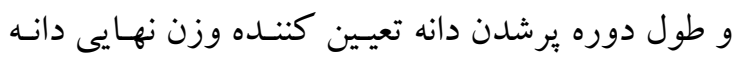

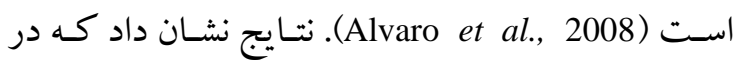

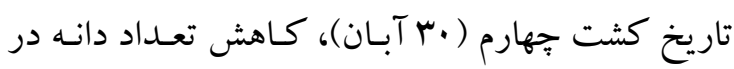
خوشه باعث افزايش وزن دانهها به علت افز ايش تسهيم

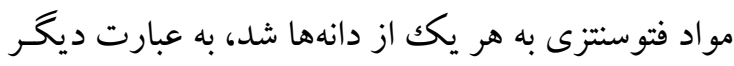

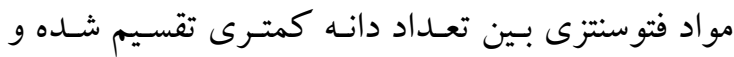

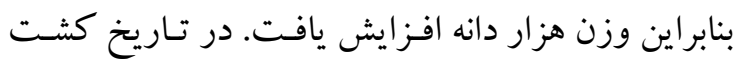

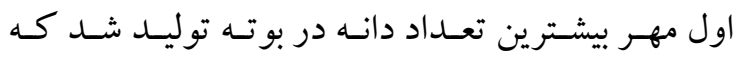
مى تواند دليل يايين بـودن وزن هزاردانه در ايسن تـاريخ

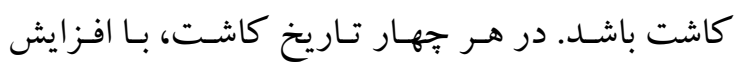
ميزان نيتروزن از صفر به ·بr كيلو گرم در هكتار، تعداد دانه در بوته افزايش يافت. افزايش مصـرف نيتـروزن بـهـ

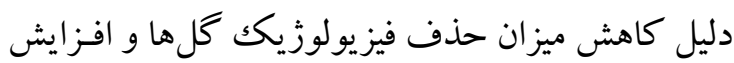

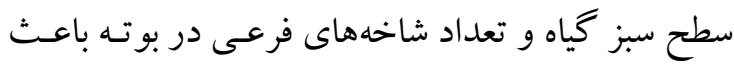

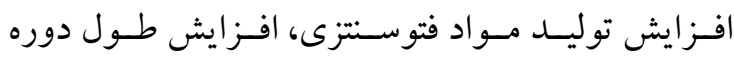

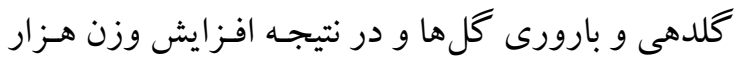

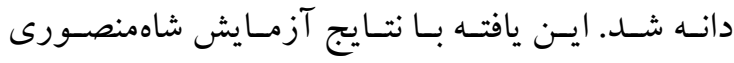
نيز مطابقت دارد. (Shahmansouri, 2015)

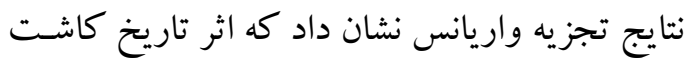

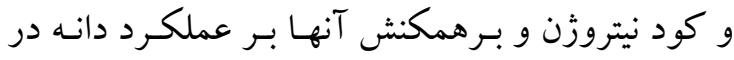

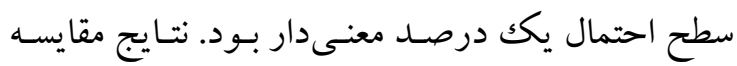

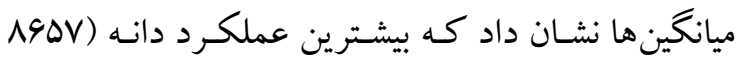

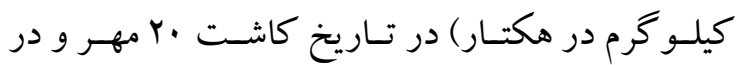
سطح •rr كيلو گرم نيتروزن در هكتار بود كه بـا تـاريخ 
مى شـود. شـو اهل زيـادى نشـان داده اسـت كـه افـزايش مصرف نيتروزن باعث افزايش وزن تكك بوته و عملكرد

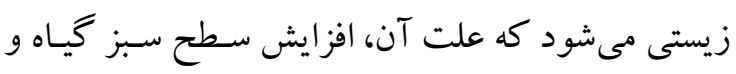

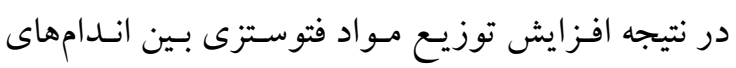

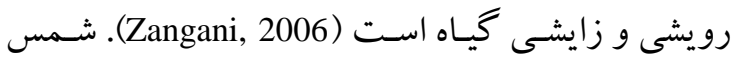
نيز در ارزيابى اثر مقادير كود نيتـروزن (Shams, 2012)

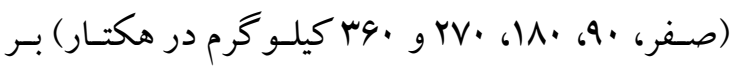

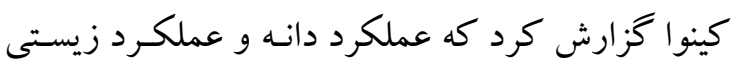

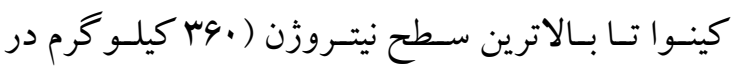

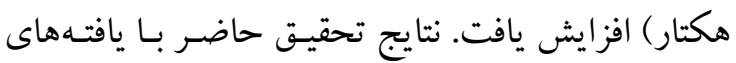

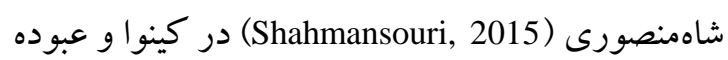
(Abodeh, 2017)

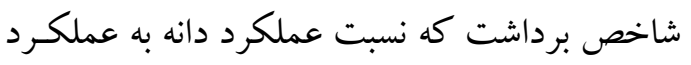

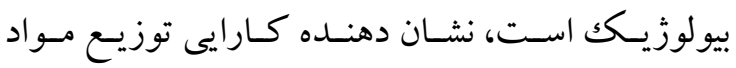

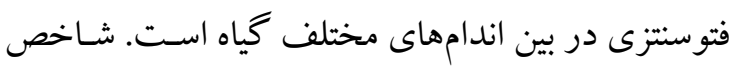

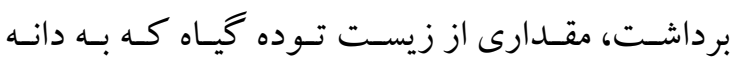

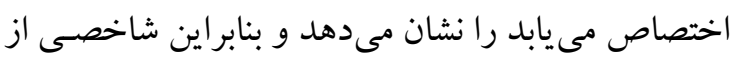

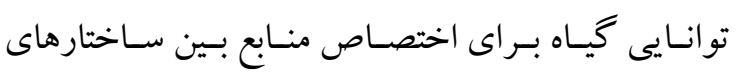
رويشى و زايشى استـ (Carrotero et al., 2010). در آزمـايش حاضـر اثـر تـاريخ كاشـت و تيمارهـاى كـود

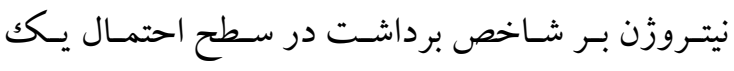

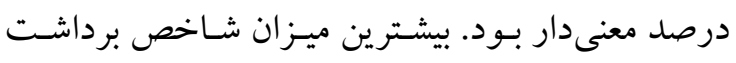

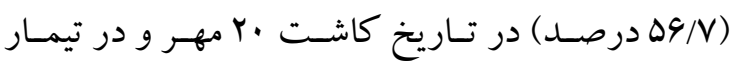
كودى • بr كيلو گرم نيتـروزن در هكتـار و كمتـرين آن

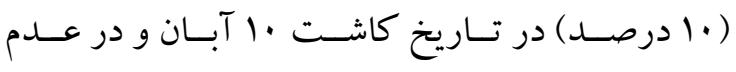
مصرف نيتروزن بدست آمد كه با تاريخ كشت ·ـ آبـان

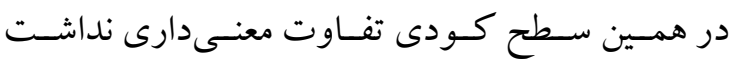
(جدول r). تاخير در كاشت تأثير زيادى بر تقسيم مـاده

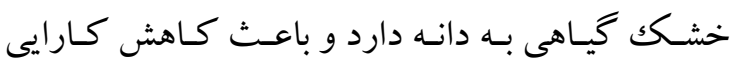

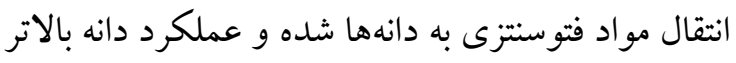
از بوتههايى حاصل مسىشـود كـه وزن خشـك بـ بيشترى داشته باشند (Chen et al., 2005). نتايج نشان داد كـه در ورد

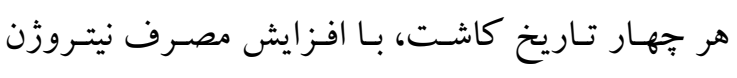
شاخص برداشت افزايش يافت، اما در تاريخ كشـت اول
كياه كينوا را نشان مىدهــ. يكى از مهم ترين عـواملى

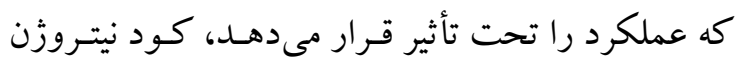

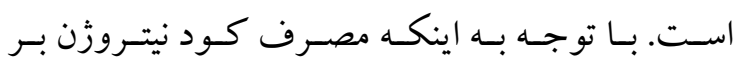

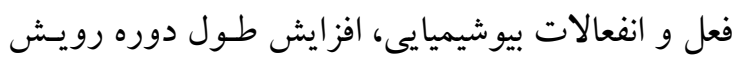

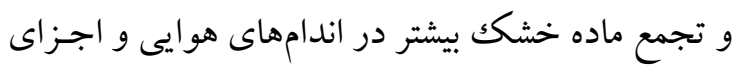

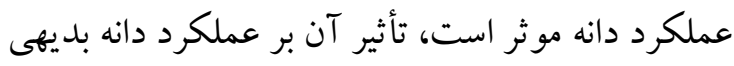
اسـت (Lloyd et al., 1997). موشــلر و همكـــاران نشان دادند كه افز ايش ميززان (Moscheler et al., 1998) نيتروزن از صـفر تـا · Fr كيلـو گرم در هكتـار، عملكـرد

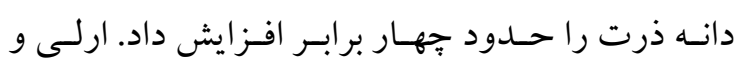

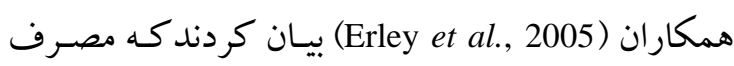

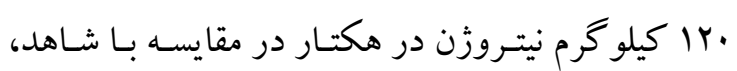

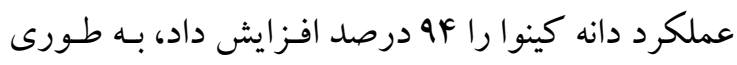

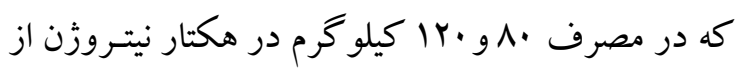

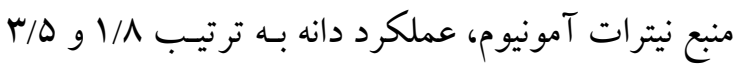

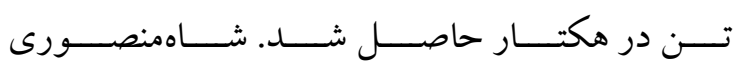
نيز در بررسى اثر نيتروزن بـر (Shahmansouri, 2015)

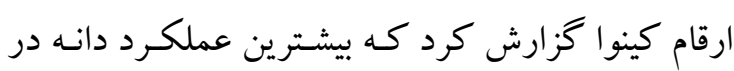

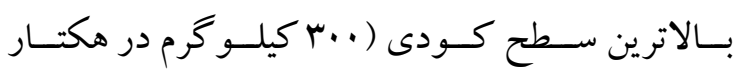
نيتروزن) در رقم تى تى كاكا مشاهده شد.

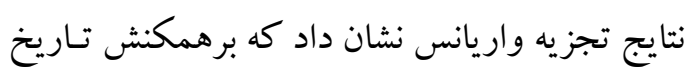

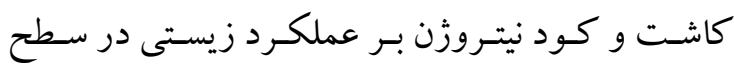

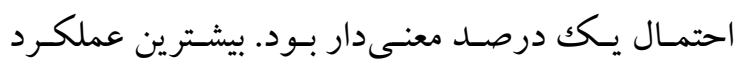

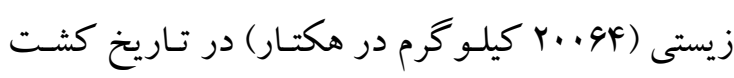

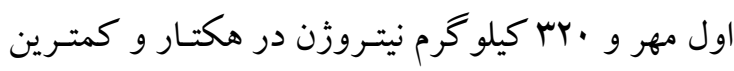

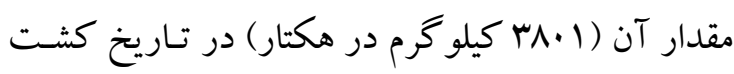

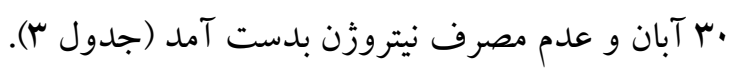

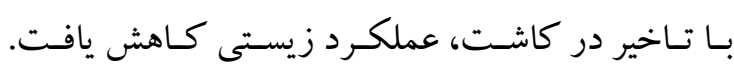

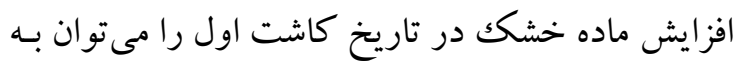

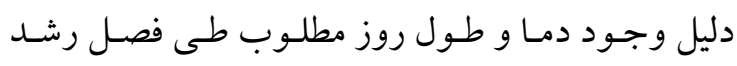

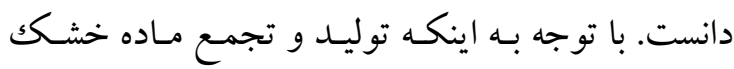

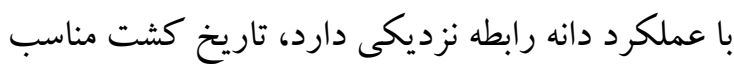

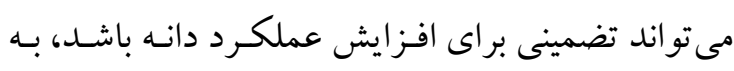

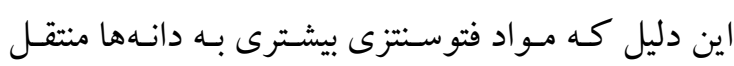


نيتروزن از مهم تـرين عناصـر مـوثر در افـزايش محتـواى

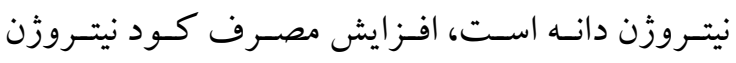

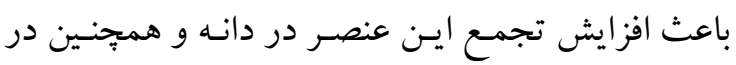

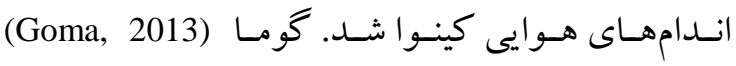

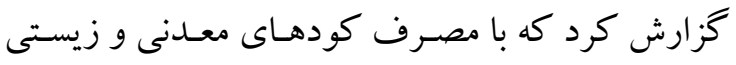
نيتروزن و فسفر، رشد، عملكرد دانه و كيفيت دانه كينـوا

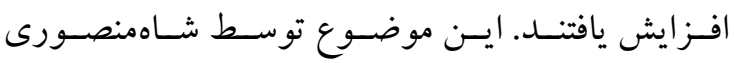

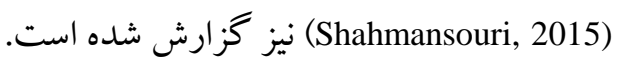

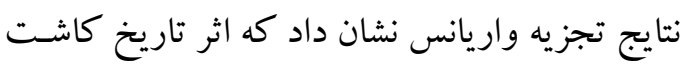

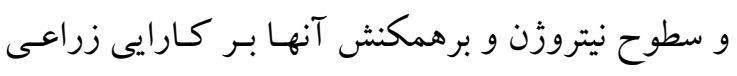

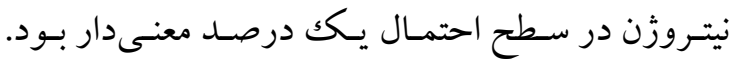

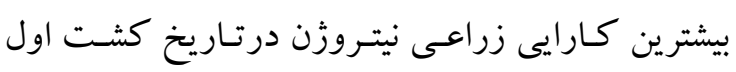

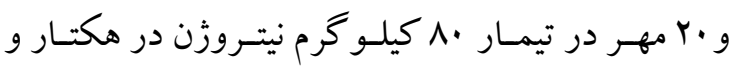

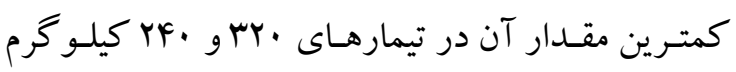

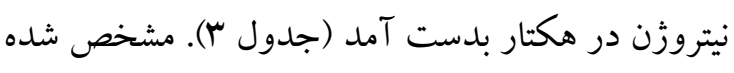

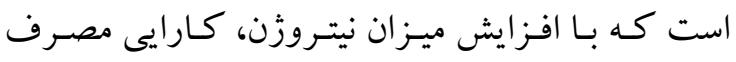

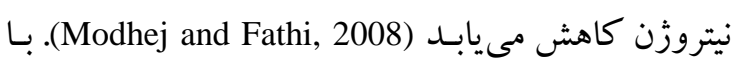
توجه به قانون بازده نزولى مبنى بر اينكه واحدهاى اوليسه

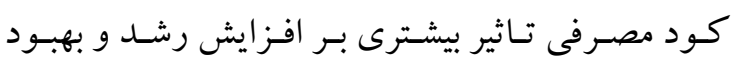

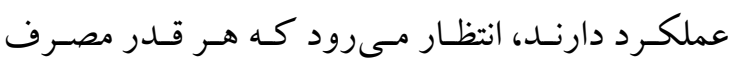

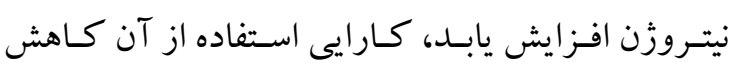

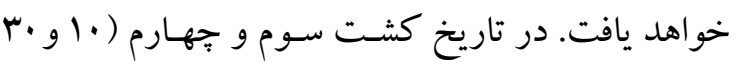

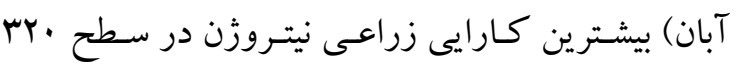

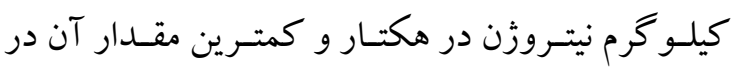

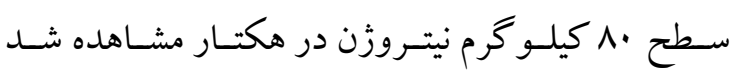
(جدول ץ). تيمسينا و همكاران (Timsina et al., 2001)

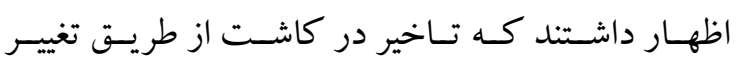

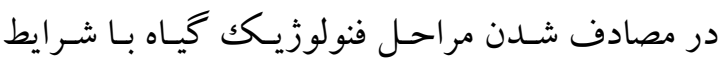

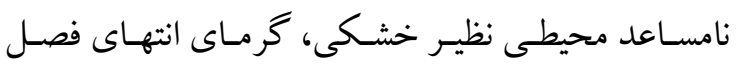

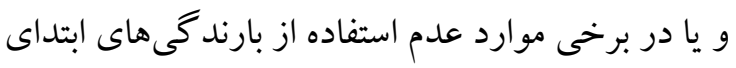

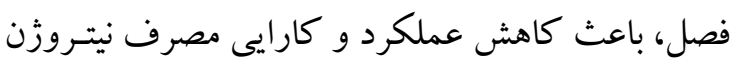

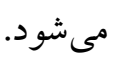
نتايج تجزيه واريانس نشان داد كه اثر تاريخ كاشت،

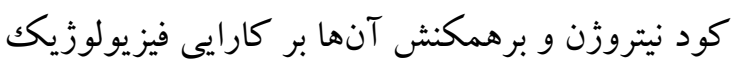

مهر با مصرف · • مس كيلو گرم نيتروزن در هكتار، افزايش عملكرد زيستى نسبت به عملكرد دانه بيشتر بود، بنابراين

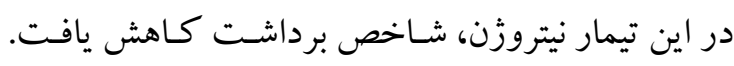

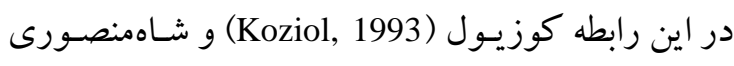
(Shahmansouri, 2015) افزايش مصرف نيتروزن، شاخص برداشت كينوا افزايش نئر يافت. نتايج تجزيه واريانس نشان داد كه اثر تاريخ كاشـت و كود نيتروزن بر محتواى نيتروزن بوته در سطح احتمال

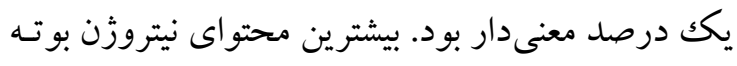

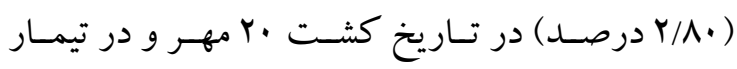

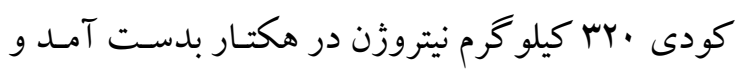

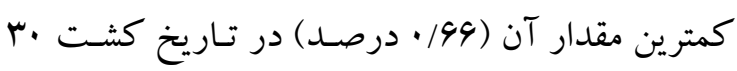

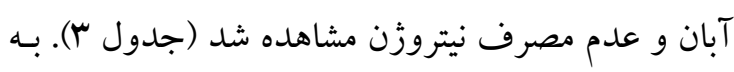
طـور كلـى كودهـاى نيتروزنسى باعـث انباشـت بيشـتر

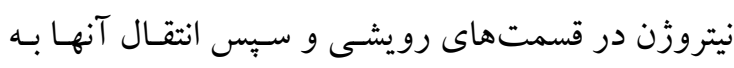

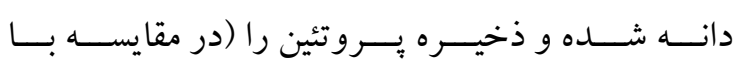

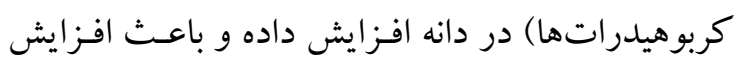

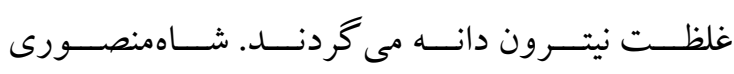

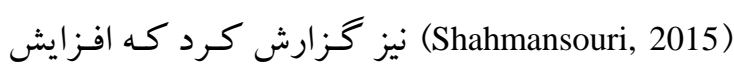
مصرف نيتروزن باعث افزايش محتو اي نيتروزن بوتسه در

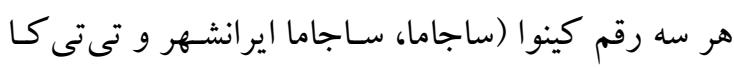
كا) شد. اثر تاريخ كاشت و كود نيتـروزن و بـرهمكنش آنها بـر محتـواى نيتـروزن دانسه معنسى دار بـود. نتـايج مقايسـهـ

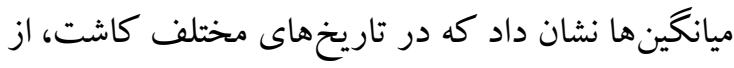

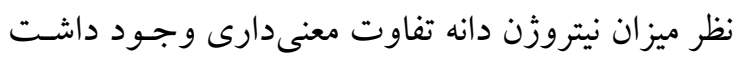

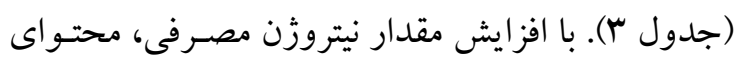

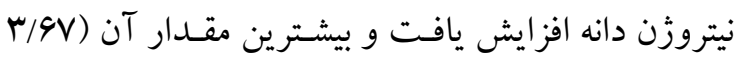

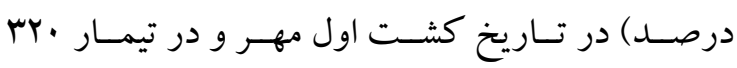
كيلـو گرم نيتـروزن در هكتـار مشـاهده شـد و و بـا تـاريخ

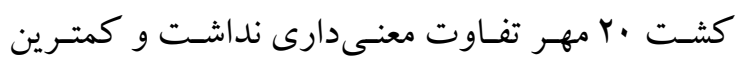

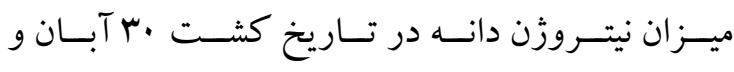

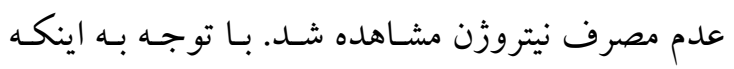


جدول r- مقايسه ميانخين صفات و شاخصهاى گياهى كينوا در تيمارهاى تاريخ كاشت و كود نيتروزن

Table 3. Mean comparison of plant traits and characteristics of Quinoa in sowing date and nitrogen fertilizer treatments

\begin{tabular}{|c|c|c|c|c|c|c|c|c|c|c|c|}
\hline $\begin{array}{c}\text { تاريخ كاشت } \\
\text { Sowing } \\
\text { date }\end{array}$ & $\begin{array}{c}\text { نيتروزن } \\
\text { Nitrogen } \\
\left(\mathrm{kg} \cdot \mathrm{ha}^{-1}\right)\end{array}$ & 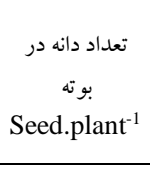 & $\begin{array}{c}\text { وزن هزار دانه } \\
1000 \text { seed } \\
\text { weight } \\
\text { (g) }\end{array}$ & $\begin{array}{c}\text { عملكرد دانه } \\
\text { Seed } \\
\text { yield } \\
\left(\mathrm{kg} \mathrm{ha}^{-1}\right) \\
\end{array}$ & $\begin{array}{c}\text { عملكرد زيستى } \\
\text { Biological } \\
\text { yield } \\
\left(\mathrm{kg}^{2} \mathrm{ha}^{-1}\right) \\
\end{array}$ & $\begin{array}{c}\text { شاخص برداشت } \\
\text { Harvest } \\
\text { index }\end{array}$ & $\begin{array}{l}\text { نيتروزن دانه } \\
\text { Seed N } \\
\text { content }\end{array}$ & $\begin{array}{l}\text { نيتروزن بوته } \\
\text { Plant N } \\
\text { content }\end{array}$ & $\begin{array}{c}\text { كارايى زراعى نيتروزن } \\
\text { NAE }\end{array}$ & كارايى فيزيولوزيكك & كارايى بازيافت ظاهرى \\
\hline \multirow{5}{*}{$\begin{array}{c}\text { اول مهر } 23 \text { Sep. }\end{array}$} & 0 & $1341.8 \mathrm{k}$ & $2.85 \mathrm{gf}$ & 595hi & $4100 \mathrm{i}$ & $14.5 \mathrm{ef}$ & $1.71 \mathrm{k}$ & $0.83 \mathrm{hij}$ & 0 & 0 & 0 \\
\hline & 80 & $3541.8 \mathrm{~h}$ & $3.02 \mathrm{ef}$ & $1619 f g$ & $9955 \mathrm{e}$ & $16.2 \mathrm{e}$ & 2.96de & $1.58 \mathrm{fg}$ & $37.1 \mathrm{a}$ & $48.3 \mathrm{a}$ & $113.4 \mathrm{a}$ \\
\hline & 160 & $11331.3 \mathrm{~d}$ & $3.09 \mathrm{de}$ & $4944 d$ & $129558 \mathrm{~cd}$ & $38.6 \mathrm{c}$ & $3.26 \mathrm{bc}$ & $1.9 \mathrm{de}$ & $25.5 b$ & $32.1 \mathrm{~b}$ & $105.4 \mathrm{~b}$ \\
\hline & 240 & $14872.5 b$ & $3.08 \mathrm{de}$ & $7312 b$ & $18348 \mathrm{a}$ & $39.8 \mathrm{bc}$ & $3.4 a b c$ & $2.29 b c$ & $22.8 b$ & $28.2 \mathrm{c}$ & $103.4 \mathrm{~b}$ \\
\hline & 320 & $16915 \mathrm{a}$ & $3.10 \mathrm{de}$ & $8000 \mathrm{a}$ & $20064 a$ & $39.8 \mathrm{bc}$ & $3.67 \mathrm{a}$ & $2.45 \mathrm{~b}$ & $22.3 b$ & $26.6 \mathrm{c}$ & $89.2 \mathrm{c}$ \\
\hline \multirow{5}{*}{$\begin{array}{l}\text { P. } \\
12 \text { Oct. }\end{array}$} & 0 & $1296.7 \mathrm{k}$ & $2.74 \mathrm{hi}$ & $551 \mathrm{j}$ & 4985hi & $11.1 \mathrm{fg}$ & $2.97 \mathrm{de}$ & $1.01 \mathrm{hi}$ & 0 & 0 & 0 \\
\hline & 80 & $3347.8 \mathrm{~h}$ & $3.00 \mathrm{ef}$ & 1582fgh & 9491ef & $16.8 \mathrm{e}$ & $3.16 \mathrm{~cd}$ & $1.99 \mathrm{~d}$ & $38.71 \mathrm{a}$ & $39.7 \mathrm{a}$ & $132.4 \mathrm{a}$ \\
\hline & 160 & $10507.5 \mathrm{e}$ & $3.39 \mathrm{c}$ & $5134 d$ & 11413de & $44.9 \mathrm{~b}$ & $3.28 b c$ & $2.47 \mathrm{~b}$ & $33.1 \mathrm{~b}$ & $26.3 b$ & $130.1 \mathrm{a}$ \\
\hline & 240 & 12027.0d & $3.90 \mathrm{~b}$ & $6507 \mathrm{c}$ & $14093 \mathrm{bc}$ & $45.7 \mathrm{~b}$ & $3.36 \mathrm{bc}$ & $2.7 \mathrm{a}$ & $25.9 \mathrm{c}$ & $24.6 b$ & $109.6 \mathrm{~b}$ \\
\hline & 320 & $13543.0 \mathrm{c}$ & $4.26 \mathrm{a}$ & $8657 \mathrm{a}$ & $15238 b$ & $56.7 \mathrm{a}$ & $3.49 \mathrm{a}$ & $2.8 \mathrm{a}$ & $24.1 \mathrm{~d}$ & $23.8 \mathrm{~b}$ & $85.22 \mathrm{~b}$ \\
\hline \multirow{5}{*}{$\begin{array}{c}\text { آبان. } 1 \text { Nov. } \\
1 \text { oo. }\end{array}$} & 0 & $1070.5 \mathrm{k}$ & $2.47 \mathrm{k}$ & $390 \mathrm{j}$ & $3808 \mathrm{jk}$ & $10.1 \mathrm{~g}$ & $1.571 \mathrm{~m}$ & $0.75 \mathrm{j}$ & 0 & 0 & 0 \\
\hline & 80 & $1475.5 \mathrm{i}$ & $2.57 \mathrm{jk}$ & 810hi & $5138 \mathrm{gh}$ & $15.7 \mathrm{e}$ & $1.95 \mathrm{jk}$ & $1.05 \mathrm{~h}$ & $3.46 \mathrm{c}$ & $21.1 \mathrm{~b}$ & $29.6 \mathrm{a}$ \\
\hline & 160 & $2679.8 \mathrm{ij}$ & 2.72ghi & 1116ghi & 6838gh & $16.3 \mathrm{e}$ & $2.1 \mathrm{ij}$ & $1.42 \mathrm{fg}$ & $4.1 b$ & $33.3 \mathrm{a}$ & $32.9 \mathrm{a}$ \\
\hline & 240 & 3192.8hij & 2.79ghi & 1307fghi & $7176 \mathrm{~g}$ & $18.2 \mathrm{e}$ & $2.29 \mathrm{hi}$ & $1.67 \mathrm{ef}$ & $4.2 \mathrm{~b}$ & $27.6 \mathrm{~b}$ & $30.1 \mathrm{a}$ \\
\hline & 320 & $3621.0 \mathrm{~h}$ & $2.89 \mathrm{ef}$ & $2327 \mathrm{e}$ & $7851 \mathrm{fg}$ & $29.8 \mathrm{~d}$ & $2.47 \mathrm{eh}$ & $1.95 \mathrm{~d}$ & $5.7 \mathrm{a}$ & $25.8 \mathrm{~b}$ & $31.1 \mathrm{a}$ \\
\hline \multirow{5}{*}{$\begin{array}{c}\text { آب r. } 21 \text { Nov. }\end{array}$} & 0 & $1030.0 \mathrm{k}$ & $2.5 \mathrm{jkl}$ & $381 \mathrm{j}$ & $3801 \mathrm{k}$ & $10.1 \mathrm{~g}$ & $1.37 \mathrm{~m}$ & $0.66 \mathrm{j}$ & 0 & 0 & 0 \\
\hline & 80 & $2493.5 \mathrm{j}$ & $2 . .63 \mathrm{ij}$ & $464 j$ & 4010ji & $11.1 \mathrm{fg}$ & $2.11 \mathrm{ij}$ & $1.39 \mathrm{~g}$ & $1.3 \mathrm{~d}$ & $22.1 \mathrm{~d}$ & $30.9 a$ \\
\hline & 160 & 3115.5hij & $3.04 \mathrm{ef}$ & $1322 \mathrm{fgh}$ & $7294 \mathrm{~g}$ & $18.1 \mathrm{e}$ & $2.37 \mathrm{hi}$ & $1.55 \mathrm{fg}$ & $6.1 \mathrm{c}$ & $27.2 \mathrm{c}$ & $27.2 \mathrm{a}$ \\
\hline & 240 & $4509.5 \mathrm{~g}$ & $3.26 \mathrm{c}$ & $2193 \mathrm{efg}$ & $7600 \mathrm{fg}$ & $27.7 \mathrm{~d}$ & $2.63 \mathrm{fg}$ & $1.98 \mathrm{~d}$ & $7.3 b$ & $29.5 b$ & $26.5 a$ \\
\hline & 320 & 6165.0f & $3.40 \mathrm{c}$ & $2953 \mathrm{e}$ & $10677 \mathrm{e}$ & $28.8 \mathrm{~d}$ & $2.75 \mathrm{ef}$ & $2.08 \mathrm{~d}$ & $8.6 \mathrm{a}$ & $30.2 \mathrm{a}$ & $30.4 a$ \\
\hline
\end{tabular}

Means in each colamn follorved by similar letter(s) are not significantly different at 5\% prohability level, using LSD test

NAE: Nitrogen Agronomic Efficiency, NPE: Nitrogen Physiological Efficiency, NARE: Nitrogen Apparent Recovery Efficiency 
•r آبان بين تيمارهاى كودى تفاوت معنى دارى وجـود.

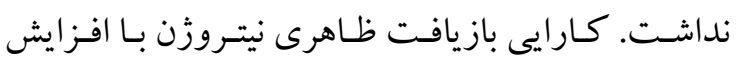

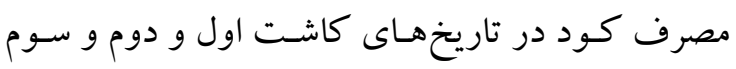

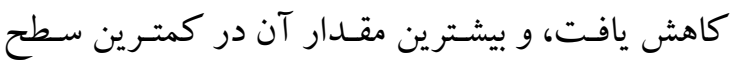

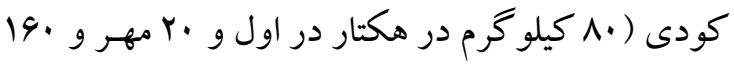

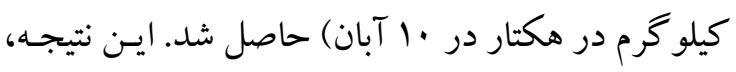
حساسيت بازيافت ظاهرى به مقدار كود مصرفى را نشان

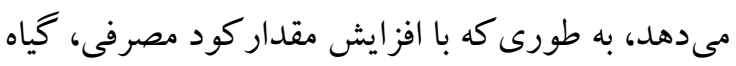

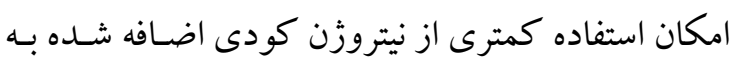
خاكك را داشته است. در تاريخ كاشت آخـر (·r آبـان)

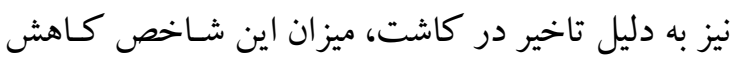

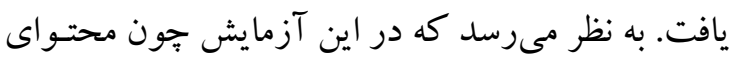
نيتروزن خاكك كم و محتو اي يتاسيم خاكك نسبتا بالا بود

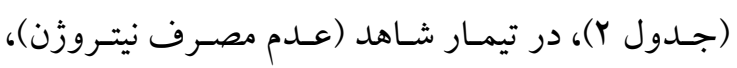

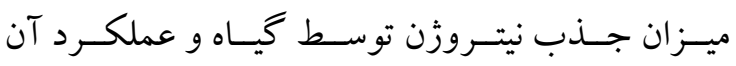

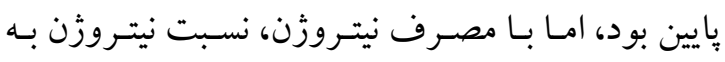

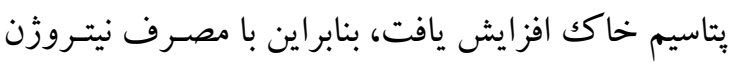

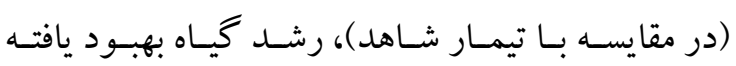

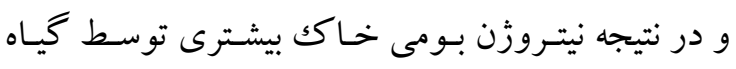

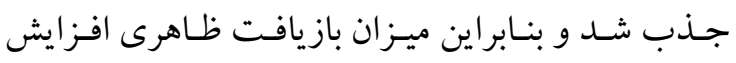
جشـمخيرى داشـت. البتـه ايسن موضسوع فقـط در تـاريخ

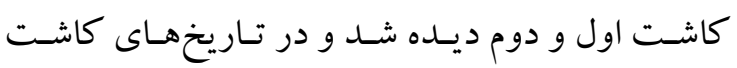
بعدى، به دليل شرايط محيطى نامناسـب و كو تـاه بـودن

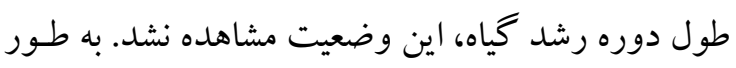

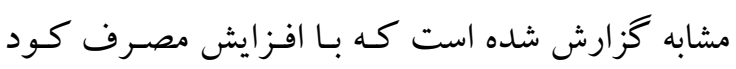

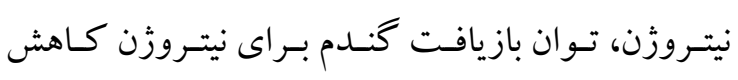
مى يابد (Dori et al., 2016).

\section{نتيجه كيرى}

نتايج آزمايش حاضر نشان داد كه يتانسيل عملكـرد

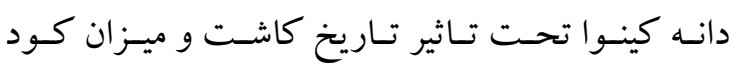

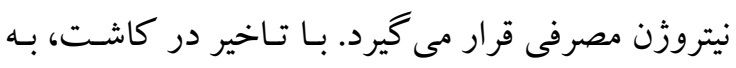

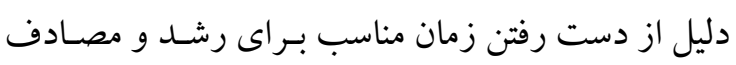

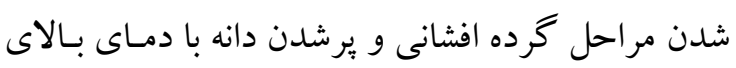

نيتروزن در سطح احتمال يكك درصد معنىدار بود. نتايج

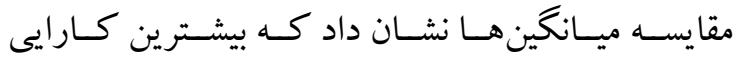

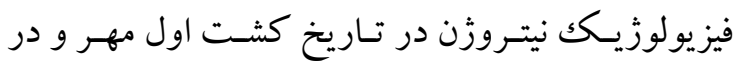
تيمار كودى •^ كيلو گرم نيتروزن در هكتـار و كمتـرين

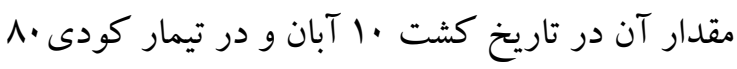

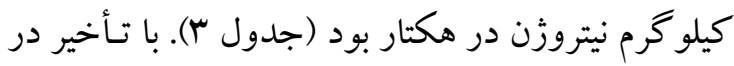

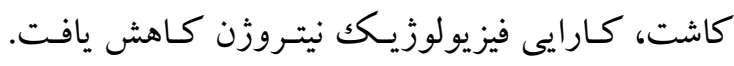

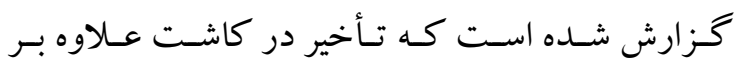
كسترش دامنه مصادف شدن مرحله بر شدن دانه با بن تنش

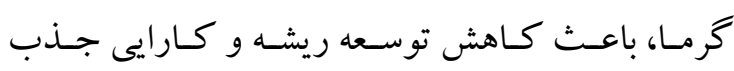

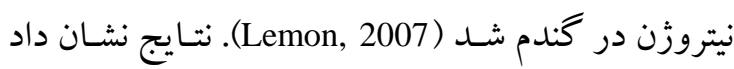
كه با افزايش مصـرف كـود در تاريخهـاى كاشـت اول،

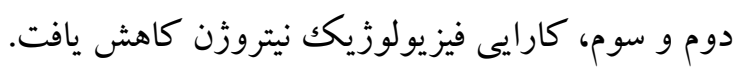

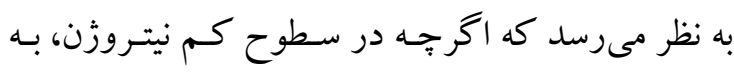

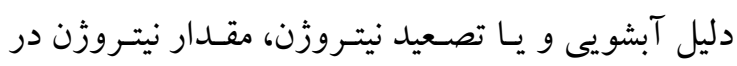

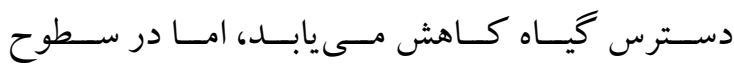
بالاى نيتروزن، مقدار تلفات ناشى از آبشـويى و تصعيد

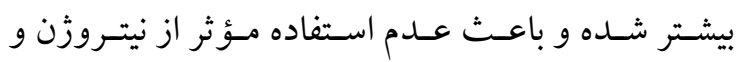

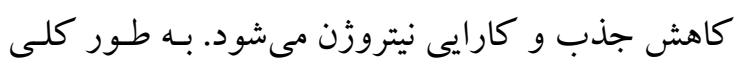

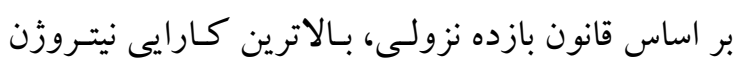

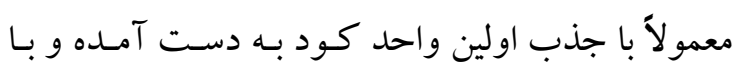

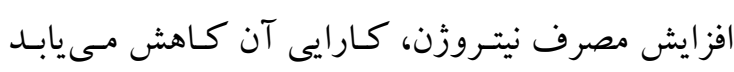

.(Modhej and Fathi, 2008) اثر تاريخ كاشت، كود نيتروزن و برهمكنش آنها بـر كارايى بازيافت ظاهرى نيتروزن (كه نشان دهنـده ميـزان

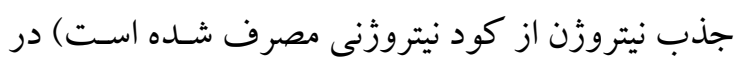

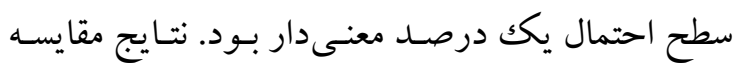

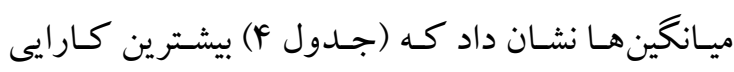
بازيافت ظاهرى نيتروزن در تاريخ كاشت اول و · ب مهر

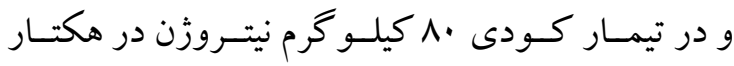

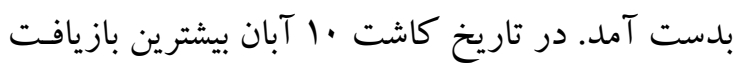

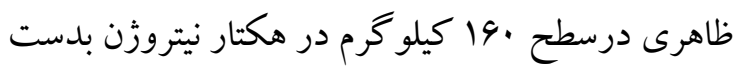

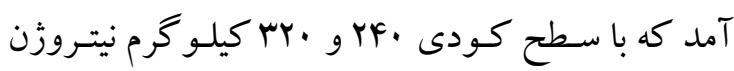

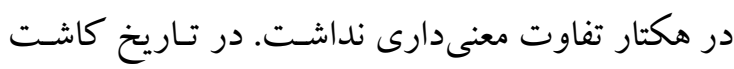




$$
\begin{aligned}
& \text { "اثر زمان كاشت و ميزان كود نيتروزن.... سعيدى و همكاران، لوبا، } \\
& \text { مهر ماه و مصرف · ·r كيلو گرم نيتروزن در هكتـار، بـا } \\
& \text { هوا، يتانسيل عملكرد گياه حاصل نشد و اين موضوع بـهـ } \\
& \text { توجه به فراهم تر بودن شرايط محيطى و تغذيهاى، باعـث }
\end{aligned}
$$

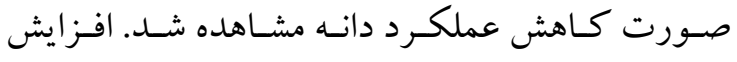

$$
\begin{aligned}
& \text { افزايش عملكرد و اجزاى آن در كينوا شد. } \\
& \text { مصرف كود نيتروزن تا حدودى اثر منفى تـنش گرمهاى } \\
& \text { سياسگزارى }
\end{aligned}
$$

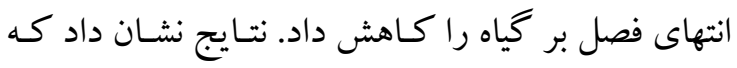

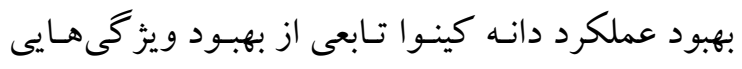

$$
\begin{aligned}
& \text { بدينوسيله از معاونت آموزشى و تحصيلات تكميلى }
\end{aligned}
$$

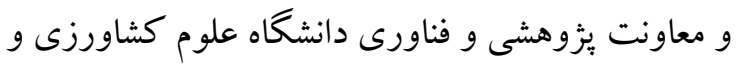

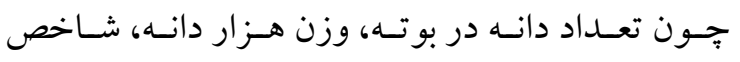

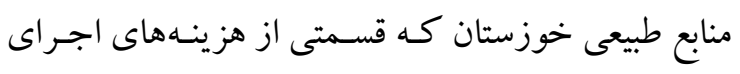

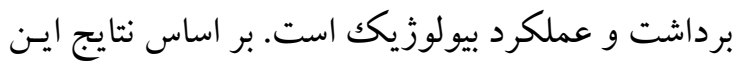

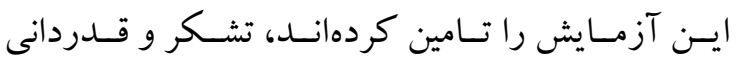

$$
\begin{aligned}
& \text { مىشود. }
\end{aligned}
$$

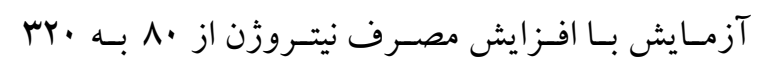

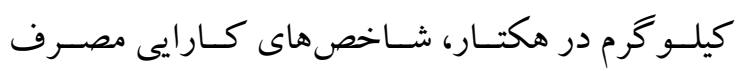

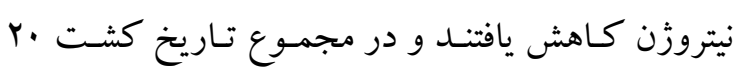

\section{References}

منابع مورد استفاده

Abodeh, H. 2017. Effect of planting date on growth and yield of safflower spring cultivar (Carthamus tinctorius L.). MSc Thesis. Agricultural Sciences and Natural Resources University of Khuzestan. (In Persian with English abstract).

Alvaro, F., J. Isidro, D. Villegas and L. F. Garcia del Moral. 2008. Breeding effects on grain filling, biomass partitioning, and remobilization in mediterranean durum wheat. Agron. J. 100: 361-370.

Bakhshandeh, A. M., A. Shengari, M. H. Gharine and Gh. Fathi. 2015. Effect of delay in planting and nitrogen levels on grain yield of morphological traits and chlorophyll index of rapeseed under weather conditions of Ahwaz. J. Agric. Res. 1: 69-73. (In Persian with English abstract).

Berti, M., R .Wilckens, F. Hevia, H. Serri, I. Vidal and C. Mendes. 2000. Fertilizaction nitrogenada en quinoa (Chenopodium quinoa Willd). Ciencia Investigsction Agraria. 27: 81-90. (In Spanish with English abstract).

Bhargava, A., S. Shukla and D. Ohri. 2006. Chonopodium quinoa- An Indian perspective. Ind. Crops Prod. 23: $73-87$.

Bremner, J. M. 1996. Nitrogen- total. p. 1085-1121. In: D. L. Spark et al., (Eds.) Methods of soil Analysis, Part 3: Chemical Methods. Soil Science Society of America: Madison, Wisconsin. USA.

Carrotero, R., R. A. Serrayo, M. O. Bnet, A. E. Perello and D. J. Miralles. 2010. Absorbed radiotion and radiation use efficiency as effected by foliar diseases in relation to their vertical position into the canopy in wheat. Field Crops Res. 916: 189-195.

Chen, H. H., Z. Y. Shenand and P. H. Li. 2005. Adaptability of crop plant to high temperature strees. Crop Sci. 22: 719-725.

Dori, S., M. R. Moradi Telavat, S. A. Siadat and A. M. Bakhshandeh. 2016. Effect of nitrogen foliar application on canola yield (Brassica napus L.) and nitrogen efficiency across different sowing dates. Iran. J. 


$$
\text { "نشريه علوم زراعى ايران"، جلد بيست و يكم، شماره F، زمستان 19سا }
$$

Field Crop Sci. 14: 484-493. (In Persian with English abstract).

Erley, G. S. A., H. P. Kaul, M. Kruse and W. Aufhammer. 2005. Yield and nitrogen utilization efficiency of the pseudocereals amaranth, quinoa and buckwheat under differing nitrogen fertilization. Eur. J. Agron. 22: 95-100.

Fageria, N. K. 2009. The Use of Nutrients in Crop Plants. CRC Press, New York. USA.

Fathi, Gh., K. Banisaeeid, S. A. Siadat and F. Ebrahimpour. 2001. Effect of different nitrogen levels and plant density on grain yield of rapeseed, cultiv arpf 7045 in Khuzestan weather conditions. 25: 43-57. (In Persian with English abstacct).

Geren, H. 2015. Effects of different nitrogen level on the grain yield and some yield components of quinoa (Chenopodium quinoa Willd.) under mediterranean climatic conditions Turk. J. Field Crops. 20: 59-64.

Goma, E. F. 2013. Effect of nitrogen, phosphorus and biofertilizers on Quinoa plant. J. Appl. Sci. Res. 9(8): $5210-5222$.

Hasanzadeh, H., GH. Shakerdargah and F. Darjani. 2014. Determine the best planting date of quinoa in the coastal strip south of Iran. $1^{\text {st }}$ Symposium in New Topics in Horticultural Sciences. 19-20 Nov. Jahrom. (In Persian with English abstacct).

Jacobsen, S. E. 1998. Developmental Stability of quinoa under European conditions. Ind. Crops Prod. 7: 169174.

Koziol, M. 1993. Quinoa: A Potential New Oil Crop. pp. 328-336. In: J. Janick and J. E. Simon (Eds.). New Crops. Wiley. New York. USA.

Lemon, J. 2007. Nitrogen management of wheat protein and yield in the Esperance pot zone. Depament of Agiculte and Food publishe. Western Australia, Perth. Bulletin 4707.

Lloyd, A., J. Webb, R. Archer and R. S. Bradly. 1997. Urea as a nitrogen fertilizer for cereals. J. Agron. Sci. 128: $263-271$.

Majidian, M. 2008. Effects of nitrogen fertilizer, manure and water stress in agro systems during different growth stages on quantities and qualitative agronomic characteristics of corn (Zea mays L.) Ph.D. Thesis. Tarbiat Modaress University, Tehran, Iran. (In Persian).

Matiasevich, S. B., M. L. Castellion, S. B. Maldonado and M. P. Buera. 2006. Water-dependent thermal transition in quinoa embroys. Thermochimica Acta. 448: 117-122.

Modhej, A. and Gh. Fathi. 2008. Wheat Physiology.Islamic Azad University Press. (In Persian).

Moscheler, W. W., G. M. Shear and D. C. Martens. 1988. Comparative yield fertilizer efficiency of nitrogen, notillage and conventionally tilled corn. Agron. J. 64: 229-231.

Mosseddaq, F. B., M. A. Bounsir, O. Khallouqand and H. Benlhabib. 2016. Optimization of quinoa nitrogen nutrition under mediterranean climatic conditions. In International Quinoa Conference. 6-8 Dec. Dubai.

Pulvento, C., M. Riccardi, A. Lavini, R. D. Andria, G. Iafelicea and E. Marconi. 2010. Field trail evaluation 


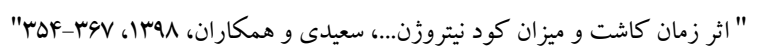

of two Chenopodium quinoa genotypes grown under rain-fed conditions in a typical Mediterranean environment in south Italy. J. Agron. Crop Sci. 196: 407-411.

Sepahvand, N. A and F. Sheikh. 2011. Familiarity with the new Quinoa plant. National Conference on Natural Products and Medicinal Plants. 4-5 Oct. Bojnourd. (In Persian with English abstract).

Sepahvand, N. A., M. Tavazoa and M. Kohbazi. 2010. Quinoa valuable plant for alimentary security and adaptation agricultural in Iran. $11^{\text {th }}$ National Iranian Crop Science Congress. 24-26 Jul. Tehran. (In Persian with English abstract).

Shahmansouri, R. 2015. Reaction of quinoa cultivars to nitrogen levels. MSc Thesis. Agricultural Sciences and Natural Resources University of Khuzestan, Iran. (In Persian with English abstract).

Shams, A. S. 2012. Response of quinoa to nitrogen fertilizer rates under sandy soil conditions. $13^{\text {th }}$ International Agronomy Conferences. 9-10 September. Benha University. Egypt.

Siadat, S. A., A. Modhej and M. Esfahani. 2013. Cereals Production. Jahad Daneshgahi Mashhad Press. (In Persian).

Tavoosi, M and N. A. Sepahvand. 2014. The effect of different sowing dates on yield, and phenological and morphological characteristics of different genotypes of Quinoa, a new plant, in Khuzestan. $1^{\text {st }}$ International and $13^{\text {th }}$ Iranian Genetics Congress. 24-26 May. Tehran, Iran. (In Persian with English abstract).

Timsina, T., U. Singh, M. Badaruddin, C. Meisner and M. R. Amin. 2001. Cultivar, nitrogen, and water effects on productivity and nitrogen-use efficiency and balance for rice-wheat sequences of Bangladesh. Field Crops Res. 72: 143-161.

Williams, J. and D. Brenner. 1995. Grain Amaranth. p. 129-186. In: J. Williams (Ed.) Cereal and Pseudocereal. Chapman and Hall. London. UK.

Zangani, E. 2006. Effect of different levels of nitrogen on growth and quantitative yield of two canola varieties in Ahvaz region. MSc Thesis. Agricultural Sciences and Natural Resources University of Khuzestan. (In Persian with English abstract). 


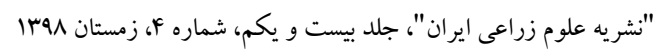

\title{
Effect of sowing time and nitrogen fertilizer rates on growth, seed yield and nitrogen use efficiency of quinoa (Chenopodium quinoa Willd) in Ahvaz, Iran
}

\author{
Saeidi, S. M. ${ }^{1}$, S. A. Siadat ${ }^{2}$, A. Moshatati ${ }^{3}$, M. R. Moradi-Telavat ${ }^{4}$ and \\ N. A. Sepahvand 5
}

\begin{abstract}
Saeidi, S.M., S. A. Siadat, A. Moshatati, M. R. Moradi-Telavat and N. A. Sepahvand. 2020. Effect of sowing time and nitrogen fertilizer rates on growth, seed yield and nitrogen use efficiency of quinoa (Chenopodium quinoa Willd) in Ahvaz, Iran. Iranian Journal of Crop Sciences. 21(4): 354-367. (In Persian).
\end{abstract}

To study the effect of sowing time and nitrogen levels on growth, yield and nitrogen efficiency of quinoa cv. Titicaca, a field experiment was conducted at in 2017-2018 growing season research farm of Agricultural and Natural Resources Sciences University of Khuzestan, Ahvaz, Iran. The experiment was conducted in split plot arrangement in randomized complete block design with four replications. Experimental factors were four sowing dates (23 Sep., 12 Oct., 1 Nov. and 21 Nov.) assigned to main plots and five nitrogen rates (0, 80, 160, 240 and $320 \mathrm{~kg} \cdot \mathrm{ha}^{-1}$ ) randomized in sub plots. Analysis of variance showed that the effect of sowing date and nitrogen rate and their interaction effect were highly significant on all traits. Mean comparison showed that the highest number of seed.plant ${ }^{-1}$ (16915), biological yield (20064 kg.ha $\left.{ }^{-1}\right)$ and seed nitrogen content (3.67\%) was observed in the sowing date of 23 Sep. and $320 \mathrm{~kg} \cdot \mathrm{ha}^{-1}$ nitrogen fertilizer. Also, the highest seed yield (8657 kg.ha-1), 1000 grain weight $(4.26 \mathrm{~g})$, harvest index $(56.7 \%)$ and plant nitrogen content $(2.80 \%)$ were observed at sowing date of 12 Oct. and $320 \mathrm{~kg} \cdot \mathrm{ha}^{-1}$ nitrogen. The lowest seed yield (381 kg.ha-1) was observed in sowing date of 21 Nov. and and no-application of nitrogen. With increasing nitrogen application from 80 to $320 \mathrm{~kg}^{-h^{-1}}$, nitrogen efficiency indices decreased. The highest seed yield of quinoa in Ahvaz can be achieved by sowing on 23 Sep. and $320 \mathrm{~kg} \cdot \mathrm{ha}^{-1}$ nitrogen.

Key words: Harvest index, Khuzestan, Quinoa, 1000 seed weight and Urea fertilizer.

\footnotetext{
Received: February, 2019 Accepted: September, 2019

1. Former MSc Student, Agricultural Sciences and Natural Resources University of Khuzestan, Ahvaz, Iran

2. Professor, Agricultural Sciences and Natural Resources University of Khuzestan, Ahvaz, Iran

3. Assistant Prof., Agricultural Sciences and Natural Resources University of Khuzestan, Ahvaz, Iran

(Corresponding author) (Email: A.Moshatati@asnrukh.ac.ir, Alimoshatati@gmail.com)

4. Associate Prof., Agricultural Sciences and Natural Resources University of Khuzestan, Ahvaz, Iran

5. Assistant Prof., Seed and Plant Improvement Institute, Agricultural Research, Education and Extension Organization, Karaj, Iran
} 